Article

\title{
The Copepod Acartia tonsa Dana in a Microtidal Mediterranean Lagoon: History of a Successful Invasion
}

\author{
Elisa Camatti *, Marco Pansera and Alessandro Bergamasco \\ Consiglio Nazionale delle Ricerche, Istituto di Scienze Marine (CNR ISMAR), Arsenale Tesa 104, Castello 2737/F, \\ 30122 Venezia, Italy; marco.pansera@ve.ismar.cnr.it (M.P.); alessandro.bergamasco@ismar.cnr.it (A.B.) \\ * Correspondence: elisa.camatti@ismar.cnr.it; Tel.: +39-041-2407-978
}

Received: 13 May 2019; Accepted: 5 June 2019; Published: 8 June 2019

check for updates

\begin{abstract}
The Lagoon of Venice has been recognized as a hot spot for the introduction of nonindigenous species. Several anthropogenic factors as well as environmental stressors concurred to make this ecosystem ideal for invasion. Given the zooplankton ecological relevance related to the role in the marine trophic network, changes in the community have implications for environmental management and ecosystem services. This work aims to depict the relevant steps of the history of invasion of the copepod Acartia tonsa in the Venice lagoon, providing a recent picture of its distribution, mainly compared to congeneric residents. In this work, four datasets of mesozooplankton were examined. The four datasets covered a period from 1975 to 2017 and were used to investigate temporal trends as well as the changes in coexistence patterns among the Acartia species before and after $A$. tonsa settlement. Spatial distribution of $A$. tonsa was found to be significantly associated with temperature, phytoplankton, particulate organic carbon (POC), chlorophyll $a$, and counter gradient of salinity, confirming that $A$. tonsa is an opportunistic tolerant species. As for previously dominant species, Paracartia latisetosa almost disappeared, and Acartia margalefi was not completely excluded. In 2014-2017, A. tonsa was found to be the dominant Acartia species in the lagoon.
\end{abstract}

Keywords: Acartia tonsa; Lagoon of Venice; nonindigenous species; zooplankton distribution; coexistence patterns; niche overlaps; long-term ecological research

\section{Introduction}

Alien invasive species, also called non-native or nonindigenous species (NIS), together with marine pollution, overexploitation of living resources, and physical alteration of habitats, represent the main threats to the world's oceans on local, regional, and global scales [1]. The planktonic crustacean Acartia tonsa Dana (1849) (calanoid copepod) is an NIS recently introduced in the Mediterranean Sea [2]. Several studies have shown that Acartia NIS are colonizing coastal areas and estuaries by propagation or introduction (e.g., [3,4]). The ability of Acartiidae to cross geographic barriers relies mainly in their capability of producing resting stages [5]. These NIS are modifying the status of native species, which are subject to competitive pressure [6]. A. tonsa is widely distributed in estuarine environments along the Atlantic coasts of North and South America [7] and the Pacific coast of North America [8] where it is the most abundant species. It appeared in the European coasts in the first half of the 20th century, possibly transferred by ship ballast waters $[9,10]$. In the Mediterranean Sea, $A$. tonsa was first reported in 1985 in the Etang de Berre, a eutrophic lagoon near Marseilles, France [2]. Only after 1985 was the presence of $A$. tonsa confirmed in several Italian transitional waters such as in a lagoon of the Po River Delta (northern Adriatic Sea) [11], in the Lagoon of Lesina [12], and in the Lagoon of Venice [13]. In estuarine ecosystems, $A$. tonsa generally reaches relatively high abundances and becomes often the 
dominant zooplankton species during summer [14], provided that high concentrations of particulate organic carbon and particulate organic matter are available. In fact, the life cycle of this copepod is strictly dependent on the quantity of the available food-the larger the trophic supplies are, the more accelerated its growth rate is [15-17].

The Lagoon of Venice, a large Mediterranean lagoon located in the northwest coast of the Adriatic Sea, presents marked habitat heterogeneity, and the classification of its habitats is still a matter of debate $[18,19]$. The lagoon is considered the main hotspot for invasive species in the whole Italian coast with the presence of more than 60 NIS, including 29 invertebrates and 34 macrophyte species among which A. tonsa also appears [20-25]. The lagoon is also part of the Long-Term Ecological Research (LTER) network (http://www.lteritalia.it), a global network of research sites located in a wide array of ecosystems. LTER research is a fundamental tool for monitoring environmental changes over time. Zooplankton communities exhibit an intrinsically high variability in transitional environments, and the elucidation of coexistence patterns is a critical question in ecology as well as in accounting for differences in abundances among species. In addition to zooplankton ecological relevance related to the role in the marine trophic network, changes in the community have implications for environmental management and ecosystem services.

This work describes relevant steps in the history of invasion and establishment of $A$. tonsa in the Lagoon of Venice with respect to local stressors. This work provides a recent picture of its distribution along gradients of environmental parameters and identifying the relevant biogeochemical quantities assisting or limiting the successful colonization of the species, mainly compared to congeneric residents in the lagoon (Acartia margalefi Alcaraz (1976), Paracartia latisetosa Krichagin (1873), and Acartia clausi Giesbrecht (1889)). The study will focus on abundance, distribution, and niche interactions of the Acartiidae community to address the question of niche separation and to investigate multidimensional niche breadths under a temporal and trophic gradient.

The work aims to identify which ecological factors are most important for $A$. tonsa population structure and organization and to provide a possible key to disentangle the roles of Acartia lagoon dominant species based on their niche characteristics. Identification or exclusion of possible overlaps among realized niches in the space of considered environmental variables will aim to highlight the specialization of each species and the relevance of coexistence mechanisms in the structuration of the community. Combining spatial and temporal frames in the three different periods taken into consideration, along a gradient from the mainland to the inlets, determining species' relative abundance distributions (RADs) in a given habitat and time will support the comparison of the reciprocal position of the species of interest within the mesozooplankton community and also how they eventually interacted in a competitive way.

\section{Materials and Methods}

\subsection{Study Area}

The Lagoon of Venice is a large Mediterranean lagoon with an area of approximately $500 \mathrm{~km}^{2}$ stretching along the northwest coast of the Adriatic Sea (Figure 1). Three inlets connect the lagoon to the sea, and its general circulation results from the superposition of tide, wind, and topographic control $[26,27]$. The effective renewal rate of water is on the order of a few days for the areas closest to the inlets and up to a month for the innermost areas $[26,28]$. Its depth is very shallow, some $1.3 \mathrm{~m}$ on average and more than $10 \mathrm{~m}$ in the deepest channels connecting the three inlets with the city of Venice and with the industrial area of Marghera. The Lagoon of Venice is surrounded by urban and industrial areas. Moreover, fishery, mariculture, and tourist activities are very developed. Because of the complex interplay of the variety of simultaneously occurring stressors, the lagoon experiences high variability in most of the environmental parameters, showing high habitat heterogeneity $[29,30]$. 




Figure 1. Study area (Lagoon of Venice, Italy) and location of sampling stations during 1975-1980 (grey triangles, including Lido), 1997-2002 (black circles), 2003-2004 (grey squares), and 2014-2017 (black triangles, including San Giuliano, Marghera, Fusina, and Lido).

\subsection{Zooplankton and Environmental Variables Datasets}

Four zooplankton datasets (DSs) from surveys carried out in the Lagoon of Venice were considered in this study: the first dataset refers to the situation before the settlement of $A$. tonsa (DS1: period 1975-1980, monthly sampling) and the three after the first record $A$. tonsa in the lagoon (DS2: period 1997-2002, monthly sampling; DS3: period 2003-2004, monthly sampling; and DS4: period 2014-2017, seasonal sampling).

The first dataset (DS1), concerning data prior to the establishment of $A$. tonsa, was used for RAD analysis to compare the different relative species' abundance distributions as a function of the presence of $A$. tonsa along an expected environmental gradient from the sea to the mainland (Lido inlet, Crevan, Dese; Figure 1). The second dataset (DS2), the most evenly distributed in terms of spatial and temporal coverage, was used to investigate patterns and trends of $A$. tonsa almost immediately after its first record in an intermediate area of the lagoon, called Palude della Rosa. In this case, zooplankton samplings were collected from May 1997 to April 2002 at five stations located in the northern part of the lagoon (San Giuliano, Marghera, Fusina, Lido, and Palude della Rosa; Figure 1) characterized by a complex interplay of freshwater and marine inputs [26,28] and by anthropogenic pressure [31]. San Giuliano collects urban waste water from the town of Mestre, where phytoplankton blooms often develop [32,33]. Marghera is influenced by industrial pollution. Fusina is affected by thermal pollution from a thermo-electric power plant. Lido, in the northernmost inlet of the lagoon, is characterized by substantial lagoon shelf exchanges. Palude della Rosa is a typical lagoon environment, influenced both by freshwater and, to a lesser extent, by shelf water transported this far by tides. 
The recent spatial distribution of $A$. tonsa populations in the lagoon, and its potential diverse response in areas subjected to different natural and anthropogenic influences, were investigated through the analysis of samples derived from monthly samplings, from April 2003 to March 2004, at six stations inside the lagoon and one station in the Adriatic Sea site just outside the Lido inlet (third data set DS3, Figure 1). Thus, with respect to the 1997-2002 stations, this dataset provided more coverage and representativeness of different areas in the lagoon with different natural and anthropogenic stressors, including a station on the outer shelf. Station 1M (Figure 1) was chosen to verify the presence of the species in the coastal sea, whereas the other stations were selected based on the following rationale: station $2 \mathrm{~B}$ was influenced by freshwaters; station $7 \mathrm{~B}$ collected urban waste; station $9 \mathrm{~B}$ was affected by thermal pollution; station $11 \mathrm{~B}$ was located in an intermediate area between northern and central lagoon basins; station 14B was in a site with seagrass meadow; and station 17B was located in the southern lagoon basin (Figure 1). Station 1M was not sampled in September 2003 and February 2004, and station 17B was not sampled in April 2003. All samples reported abundances of phytoplankton and mesozooplankton organisms as well as physical and chemical parameters related to water quality, in particular: temperature, salinity, dissolved oxygen, chlorophyll $a$, and particulate organic carbon (POC).

Samples related to the most recent period 2014-2017 (DS4) were used to confirm the presence and distribution of $A$. tonsa ten years after the previous survey along a gradient from the inner lagoon to the outer shelf. In this case, eight stations were sampled. The Inside station (Figure 1) was located in the inner channel inside the industrial harbour of Marghera, Port1 was in the lee of the cruise ships docks, 7M was at the yachting mooring docks, and PTF was the CNR Acqua Alta Oceanographic tower (http://www.ismar.cnr.it/infrastructures/piattaforma-acqua-alta), situated few miles offshore the lagoon in the Northern Adriatic. The remaining four stations corresponded to Marghera, Fusina, San Giuliano, and Lido sites of the period 1997-2002. All the considered 65 samples reported abundances of mesozooplankton organisms (66 present taxa) as well as physical and chemical parameters related to water quality, in particular: temperature, salinity, dissolved oxygen, chlorophyll $a$, nutrients, and Secchi disk.

Sampling procedures and analyses were performed in the same way for all datasets; thus, data from different years and projects were homogeneous and comparable with each other. Zooplankton samples were collected by a plankton horizontal sampler (200 $\mu \mathrm{m}$ mesh net size) and preserved with borax buffered formaldehyde for microscopic analysis. Taxonomic and quantitative zooplankton determinations were performed using a Zeiss stereomicroscope at the lowest possible taxonomic level (species for copepods and cladocerans). Each sample was poured into a beaker with $200 \mathrm{~cm}^{3}$ of filtered seawater to allow a thorough mixing for random distribution of the organisms. At least four aliquots of the samples were analysed while the entire sample was checked against the identification of rare species [34,35]. Phytoplankton samples resulting from the DS3 were collected in $250 \mathrm{~cm}^{3}$ dark glass bottles and fixed with $10 \mathrm{~cm}^{3}$ of $20 \%$ hexamethylentetramine buffered formaldehyde [36]. Counts were taken according to Utermöhl's (1958) [37] method, using an inverted microscope (Zeiss Axiovert 35) after 2 to $10 \mathrm{~cm}^{3}$ subsamples had settled for $24 \mathrm{~h}$ [38]. Temperature, salinity, and dissolved oxygen were measured in situ using a CTD (Conductivity Temperature Depth) Idronaut Ocean Seven 316 Multiprobe. Particulate organic carbon (POC) was determined using a CHN (Carbon Hydrogen Nitrogen) analyser [39], whereas surface chlorophyll $a(\mathrm{Chl} a)$ was analysed with spectrophotometric methods [40].

\subsection{Statistical Analyses}

In order to characterize and explain the A. tonsa population dynamics and trends after its arrival in the lagoon, a seasonal Kendall test (SK) [41] was performed over the data set 1997-2002 (DS2). The test performed the Mann-Kendall (MK) trend test for individual seasons of the year, where season was defined by the user (here, corresponding to monthly values). It then combined the individual 
results into an overall test to depict whether the dependent variable changed in a consistent direction (monotonic trend) over time or not.

To ascertain if species abundances and environmental parameters were associated, the nonparametric Kendall rank correlation test was carried out [42] on the 2003-2004 dataset (DS3). A correspondence analysis (CA) [43] was carried out on this dataset to highlight the possible relationships and groupings between stations (representative of different habitats) and zooplankton species (proxy of different water masses). CA is the most suitable statistical technique to analyse enumerative data [44]. As it is based on the chi squared metric, this algorithm automatically weights both low and high frequencies. The dataset was organized in a species/station matrix. Statistical analyses were performed using MATLAB ${ }^{\circledR}$ software.

Species RADs were used to support the comparison of the whole zooplankton community throughout the four decades and the different habitats covered by the available datasets. In particular, three types of habitats were identified along a gradient from the mainland to the sea: the innermost shallow zones characterized by low water circulation (inner), the inlet areas at the interface between the lagoon and the Adriatic Sea with strong marine characters (inlet), and the transition areas with less direct links to the sea (intermediate). For these three habitats, all available samples of each of the three decades (decade D1: 1975-1985, from data set DS1; decade D3: 1995-2005, from data set DS3; recent period D4: 2005-2017, from DS4) were integrated to obtain $3 \times 3$ snapshots (before invasion, early settlement, and more mature condition in each habitat) of the RADs of the overall zooplankton community.

Relationships between environmental variables and zooplankton community composition in the current decade (D4)-with particular focus on A. tonsa and the congeneric A. margalefi, P. latisetosa, and A. clausi-were studied using an outlying mean index (OMI) analysis through the 'ade4' package in $\mathrm{R}$, extended to the overall zooplankton taxa (dataset DS4). OMI analysis [45] is a multivariate technique to perform niche analyses of species assemblages and explore the relationships between environmental gradients and community structure. The focus is on a specialization criterion called OMI index (i.e., species marginality), which measures the distance between the average habitat conditions used by each species and the average habitat conditions of the sampling area. To characterize the realized niche of each species, the analysis extracts two other terms: the tolerance index (Tol), which measures the habitat breadth of the species, and the residual tolerance (RTol), which represents the variance in the species niche not explained by the measured environmental variables.

\section{Results}

During the decade before the first record of A.tonsa in lagoon (DS1), the mesozooplankton community was composed of more than 40 taxa, with a weak decreasing gradient of overall richness from the inlet (46 taxa) to the intermediate areas (43 taxa) and to the inner zone (41 taxa). Among them, copepods were represented by 24 species, and Acartiidae largely dominated the community with A. clausi being the most abundant taxon in every habitat. The species $A$. tonsa was not present in any sample of DS1, even in the innermost areas, where the three dominant species (A. clausi, A. margalefi, P. latisetosa) represented more than $80 \%$ of the overall community.

Conversely, over the analysed 1997-2002 period (DS2), A. tonsa reached higher abundances at the inner lagoon stations San Giuliano (Figure 2) and Palude della Rosa (Figure 2) and constituted about $90 \%$ of the lagoon mesozooplankton community (Figure 3). Seasonal cycles (Figure 2) showed that the species was, generally, nearly absent in the cold season while annual peaks in abundances were reached in summer. The population started to rapidly increase in May, when suitable water temperatures $\left(>15^{\circ} \mathrm{C}\right)$ assisted the growth, and decreased in fall. Annual maxima were reached in different months, depending mainly on the station features. San Giuliano and Palude della Rosa, the stations with larger abundances, had annual peaks in July. 



Figure 2. Box plot of monthly A. tonsa abundance from the dataset 1997-2002 for the five sampled stations (San Giuliano, Marghera, Fusina, Lido, and Palude della Rosa). The cross ( $\mu$ ) indicates the average, $25-75 \%$ indicates the interquartile range, and $10-90 \%$ indicates the interdecile range. 




Figure 3. Relative abundance, station by station, of $A$. tonsa with respect to the other Acartia species and the remaining zooplankton during the 1997-2002 period.

SK analysis showed a statistically significant increase of the species only at the San Giuliano station (Table 1) along with total zooplankton abundance. The positive trend of total zooplankton appeared to be due to A. tonsa exclusively. At Palude della Rosa, the second station in order of abundance, the trend of $A$. tonsa and total zooplankton abundance was also positive, although not statistically significant (Table 1). In the other stations, where $A$. tonsa abundance was generally lower and reached the minimum at Lido station, the trend was found to be negative and not significant (Table 1).

Table 1. Results of the seasonal Kendall test (1997-2002 period).

\begin{tabular}{|c|c|c|c|c|c|}
\hline & & Acartia clausi & Acartia margalefi & Acartia tonsa & $\begin{array}{c}\text { Total } \\
\text { Zooplankton }\end{array}$ \\
\hline \multirow{2}{*}{ San Giuliano } & Tau & -0.121 & -0.577 & 0.243 & 0.300 \\
\hline & $\mathrm{p}$ & 0.311 & 0.000 & 0.040 & 0.011 \\
\hline \multirow{2}{*}{ Fusina } & Tau & -0.125 & -0.687 & -0.009 & -0.008 \\
\hline & $\mathrm{p}$ & 0.303 & 0.000 & 0.943 & 0.943 \\
\hline \multirow{2}{*}{ Marghera } & Tau & -0.346 & -0.728 & -0.153 & -0.142 \\
\hline & $\mathrm{p}$ & 0.003 & 0.000 & 0.199 & 0.228 \\
\hline \multirow{2}{*}{ Lido } & Tau & -0.144 & -0.540 & -0.094 & -0.083 \\
\hline & $\mathrm{p}$ & 0.225 & 0.003 & 0.430 & 0.480 \\
\hline \multirow{2}{*}{$\begin{array}{c}\text { Palude della } \\
\text { Rosa }\end{array}$} & Tau & -0.059 & -0.688 & 0.078 & 0.067 \\
\hline & $\mathrm{p}$ & 0.620 & 0.000 & 0.514 & 0.572 \\
\hline
\end{tabular}

Despite the positive, significant trend of A.tonsa at San Giuliano, the estimate of Sen's slope [46] was 30 ind (number of individuals) $/ \mathrm{m}^{3} /$ year. This negligible increase over time (Figure 4) may be suggestive of a steady state of the population (i.e., a mature stage of colonization). Alongside the significantly increasing trend of $A$. tonsa abundance at the San Giuliano station, SK highlighted an opposite trend for the other representative species of the Acartia genus historically relevant in the lagoon: A. margalefi and A. clausi (Table 1). In particular, A. margalefi significantly (in a statistical sense) decreased at all stations, providing additional evidence of the ongoing decline in abundance of this species. 


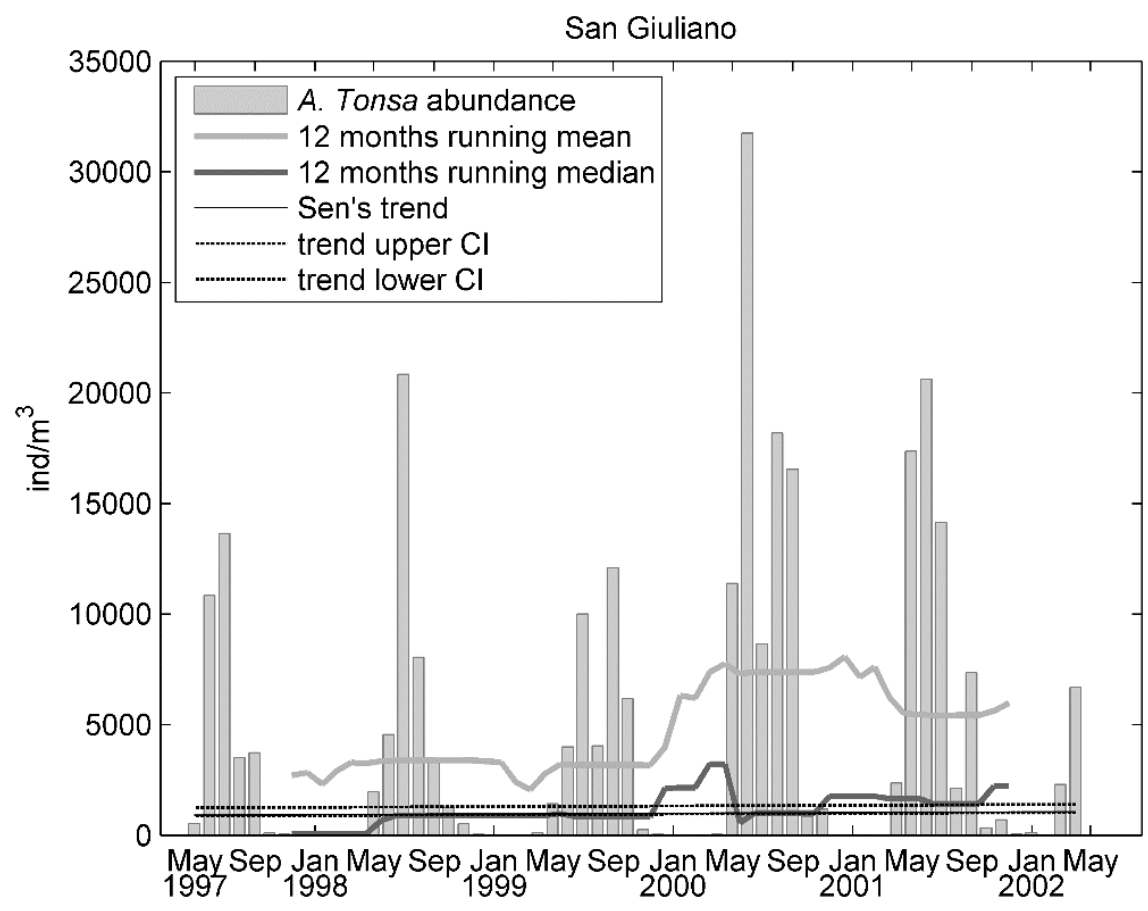

Figure 4. Time series of monthly A. tonsa abundance (bars) along with a 12-month running mean and median and Sen's trend line at the San Giuliano station during 1997-2002.

Analyses related to the April 2003 to March 2004 period (DS3) allowed characterization of the actual distribution of $A$. tonsa over an environmental gradient in the Lagoon of Venice. The presence of a decreasing gradient of salinity can be noted, shifting from stations near inlets to stations well inside the lagoon (Table 2). Higher mean salinity values were found at station 14B, which was located near an inlet and, therefore, directly influenced by tidal exchanges, and the marine coastal station $1 \mathrm{M}$ (Table 2). Lower salinity values were observed at the innermost stations (2B, 7B, and 9B). The presence of $A$. tonsa at station $1 \mathrm{M}$ was negligible and exclusively was due to ebb tidal transport, as this species is usually not resident in marine waters. Indicators of trophic water quality-particulate organic carbon (POC), $\mathrm{Chl} a$ concentration, and phytoplankton abundance-showed an opposite gradient with respect to salinity, with the larger values at stations $2 \mathrm{~B}, 7 \mathrm{~B}$, and $9 \mathrm{~B}$ (Table 2). The species recorded the largest abundances in those stations (2B and 9B) where POC, $\mathrm{Chl} a$, and phytoplankton values were high and where also the mean annual mesozooplankton abundances were highest $(6386 \pm 10,327$ and $4892 \pm$ 11,350 ind $\mathrm{m}^{-3}$ respectively; Table 2). Lowest abundance at the site $14 \mathrm{~B}$ corresponded to the lowest concentrations of POC and Chl $a$ as well as low phytoplankton abundance (Table 2).

Percentage contributions of the most abundant taxa to total zooplankton community in each station are reported in Table 3. A few species, such as the copepods A. tonsa, A. clausi, Paracalanus parvus Claus (1863), and Centropages ponticus Karavaev (1895), were always present in the zooplankton community over the whole investigated area with a percentage contribution greater than $76 \%$. A. tonsa was the most abundant in all lagoon stations with the exception of $14 \mathrm{~B}$ and $1 \mathrm{M}$ stations, which were dominated by A. clausi. The percent contributions of the codominants P. parvus and C. ponticus were generally lower than $5 \%$ except for the $14 \%$ contribution of P. parvus at site $1 \mathrm{M}$. The cladoceran Penilia avirostris Dana (1849) was present only at the marine coastal station 1M. The other taxa (i.e., decapods larvae) contributed with low abundances to zooplankton composition. 
Table 2. Average and standard deviation values of the hydro-chemical data and biological concentrations (phytoplankton, $A$. tonsa, and main mesozooplankton groups) at the seven stations for the 2003-2004 period.

\begin{tabular}{|c|c|c|c|c|c|c|c|c|c|c|c|c|c|c|}
\hline \multirow{2}{*}{ Stations } & \multicolumn{2}{|c|}{$1 \mathrm{M}$} & \multicolumn{2}{|c|}{ 2B } & \multicolumn{2}{|c|}{ 7B } & \multicolumn{2}{|c|}{ 9B } & \multicolumn{2}{|c|}{ 11B } & \multicolumn{2}{|c|}{ 14B } & \multicolumn{2}{|c|}{ 17B } \\
\hline & Avg & SD & Avg & SD & Avg & SD & Avg & SD & Avg & SD & Avg & SD & Avg & SD \\
\hline Temperature $\left({ }^{\circ} \mathrm{C}\right)$ & 16 & 8 & 16 & 9 & 17 & 9 & 18 & 8 & 16 & 10 & 16 & 10 & 16 & 9 \\
\hline Salinity & 35 & 2 & 29 & 4 & 32 & 4 & 32 & 3 & 34 & 3 & 35 & 2 & 33 & 4 \\
\hline Relative oxygen (\%) & 96 & 5 & 100 & 9 & 102 & 15 & 90 & 7 & 83 & 19 & 92 & 7 & 95 & 5 \\
\hline $\operatorname{POC}\left(\mu \mathrm{g} \mathrm{L}^{-1}\right)$ & 308 & 73 & 750 & 630 & 747 & 415 & 668 & 386 & 485 & 211 & 345 & 141 & 947 & 886 \\
\hline Chlorophyll $a\left(\mu \mathrm{g} \mathrm{L}^{-1}\right)$ & 1.78 & 0.92 & 4.40 & 4.32 & 7.02 & 6.21 & 7.81 & 12.69 & 2.09 & 1.46 & 1.54 & 0.55 & 3.84 & 4.52 \\
\hline Total phytoplankton (cell $\mathrm{L}^{-1}$ ) & 2541 & 3176 & 10,831 & 16,019 & 4382 & 4592 & 5716 & 6874 & 2082 & 2406 & 2128 & 1993 & 8318 & 15,745 \\
\hline Acartia tonsa $\left(\right.$ ind $\mathrm{m}^{-3}$ ) & 23 & 69 & 5998 & 10,333 & 976 & 1658 & 4456 & 11,209 & 2823 & 4986 & 75 & 192 & 1234 & 2744 \\
\hline Other copepods (ind $\mathrm{m}^{-3}$ ) & 3702 & 5494 & 316 & 415 & 521 & 1015 & 257 & 312 & 602 & 588 & 588 & 1170 & 144 & 167 \\
\hline Cladocerans (ind $\mathrm{m}^{-3}$ ) & 186 & 328 & 2 & 5 & 8 & 26 & 4 & 10 & 9 & 14 & 8 & 22 & 0 & 1 \\
\hline Other zooplankton (ind $\mathrm{m}^{-3}$ ) & 142 & 115 & 69 & 110 & 136 & 290 & 176 & 244 & 161 & 272 & 56 & 54 & 42 & 53 \\
\hline Total zooplankton (ind $\mathrm{m}^{-3}$ ) & 4053 & 5906 & 6386 & 10328 & 1642 & 2062 & 4893 & 11349 & 3595 & 5207 & 727 & 1233 & 1419 & 2781 \\
\hline
\end{tabular}


With respect to the entire zooplankton community, total abundances increased in late spring and summer at all stations except $1 \mathrm{M}$ where, instead, spring maxima were observed in May $\left(17 \times 10^{3}\right.$ ind $\left.\mathrm{m}^{-3}\right)$ and June $\left(8 \times 10^{3}\right.$ ind $\left.\mathrm{m}^{-3}\right)$ mainly because of the copepod A. clausi (Figure 5). Similar to the datasets 1997-2002 (DS2), the warm season corresponded to the maxima in abundances of $A$. tonsa. In general, the main mesozooplankton groups showed seasonal fluctuations with maxima during warm periods; copepods dominated throughout the year. A. margalefi showed very low abundances (maximum mean value of 10 ind $\mathrm{m}^{-3}$ in June), while P. latisetosa was never found. The rest of the zooplankton community was mainly represented by the meroplankton, especially by decapod, gastropod, and cirriped larvae during the spring and summer periods (Figure 5).


Figure 5. Monthly abundance of $A$. tonsa with respect to other Acartia species and remaining zooplankton at coastal station 1M (top panel) and at lagoon stations (bottom panel) for the 2003-2004 period.

A match between abundances and distribution of $A$. tons $a$ and environmental parameters emerged from the Kendall rank correlation test for DS3 (Table 4), which showed that $A$. tonsa was the only species of dominant copepods positively and significantly correlated with temperature, phytoplankton, POC and $\mathrm{Chl}$ a concentrations, as well as $A$. margalefi species. However, the positive correlation of A. margalefi with POC was not significant. With respect to the same parameters, the congener A. clausi showed the opposite correlation and was not statistically significant. 
Table 3. Mean percentage contributions of the most abundant species/taxa at the seven stations for the 2003-2004 period.

\begin{tabular}{|c|c|c|c|c|c|c|c|}
\hline & $1 \mathrm{M}$ & 2B & 7B & 9B & 11B & $14 B$ & 17B \\
\hline Acartia clausi & 69 & 1 & 21 & 1 & 8 & 59 & 4 \\
\hline Acartia tonsa & 1 & 94 & 59 & 91 & 79 & 10 & 87 \\
\hline Centropages ponticus & 4 & 1 & 2 & 1 & 2 & 2 & 1 \\
\hline Corycaeus spp. & 1 & & & & & & \\
\hline Harpacticoid spp. & & & 3 & & & 2 & 1 \\
\hline Oithona similis & 1 & & & & & 6 & \\
\hline Oncaea spp. & & & & & & 2 & \\
\hline Paracalanus parvus & 14 & 2 & 4 & 2 & 5 & 5 & 2 \\
\hline Pseudocalanus elongatus & 1 & & & & 1 & 1 & 1 \\
\hline Penilia avirostris & 1 & & & & & & \\
\hline Podon polyphemoides & 3 & & & & & & \\
\hline Chaetognaths & 1 & & & & & & \\
\hline Cirriped larvae & & & 1 & 1 & & & \\
\hline Decapod larvae & & & 6 & 2 & 3 & 1 & 1 \\
\hline Fish eggs & 1 & & & 1 & & & \\
\hline Gastropod larvae & & & & & & 2 & \\
\hline
\end{tabular}

Table 4. Results of the Kendall rank correlation test at seven stations for the 2003-2004 period. Statistically significant values are marked in bold.

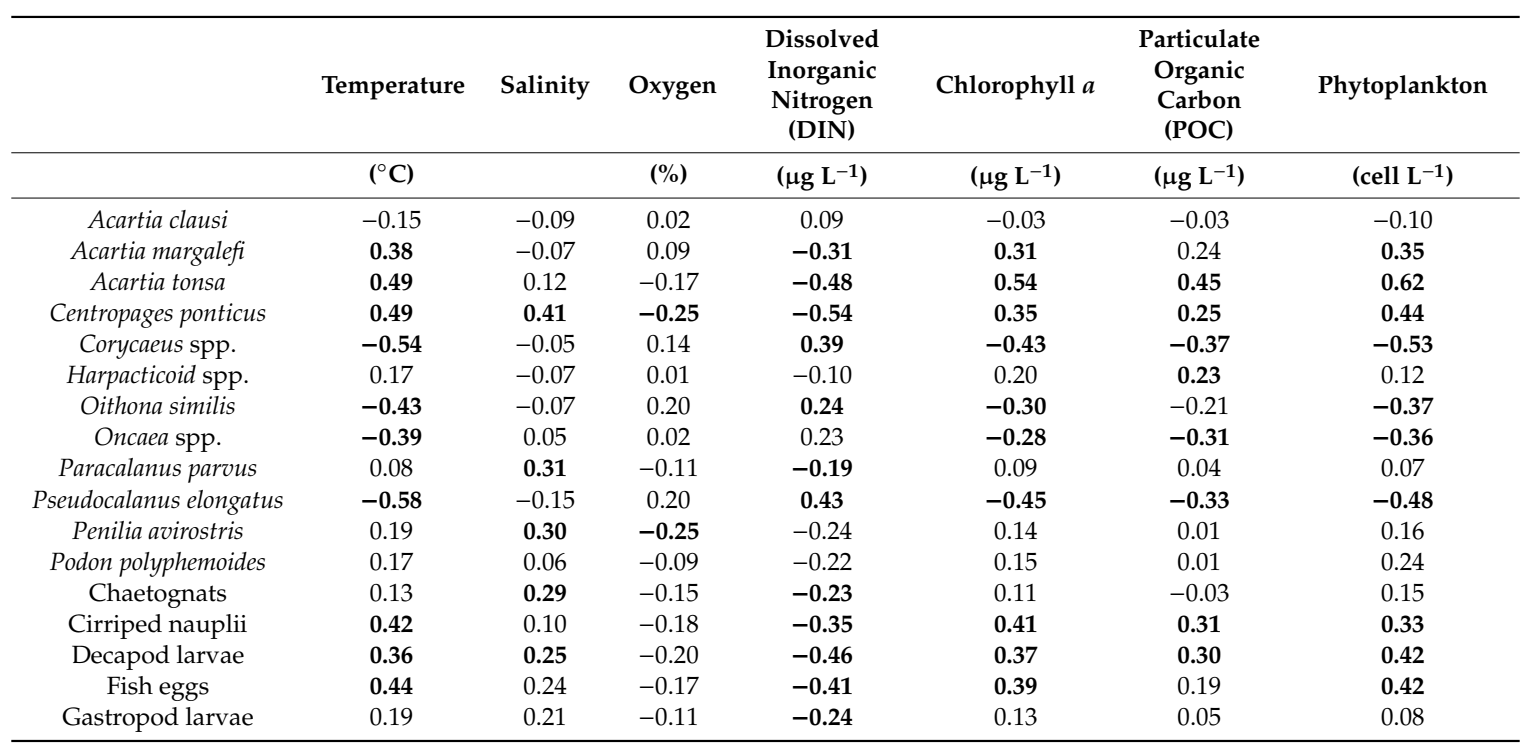

The $C A$ was suggestive of a separation of the stations into one main group, which included lagoon stations $2 \mathrm{~B}, 9 \mathrm{~B}, 17 \mathrm{~B}, 11 \mathrm{~B}$, and $7 \mathrm{~B}$, and the other two isolated stations located (i) in an area filled by seagrass in the central basin close to an inlet (14B), which was heavily influenced by tidal exchanges, and (ii) the coastal station $1 \mathrm{M}$ (Figure 6). The main group, associated mainly with inner lagoon sites, included all stations where $A$. tonsa dominated and where all trophic parameters favored its abundance. These stations had common species compositions because their species percentage distributions were similar with respect to all other stations. In fact, the same species percentage distribution considerably differed at the inlet station 14B and coastal station 1M. Indeed, Figure 7 shows that station 14B was characterized by a more heterogeneous community at the taxa level, and that higher percentages of marine taxa prevailed at station $1 \mathrm{M}$ such as appendicularians and cladocerans P. avirostris, Evadne spp., and Podon polyphemoides Leuckart (1859). The strictly neritic species A. clausi was found in both stations $1 \mathrm{M}$ and $14 \mathrm{~B}$, sites with high salinity and low inorganic nutrient waters, confirming the preference 
for coastal waters. Station 7B, the most distant in CA space from the other lagoon stations, was characterized mainly by the presence of $A$. margalefi, fish larvae, and copepod nauplii.

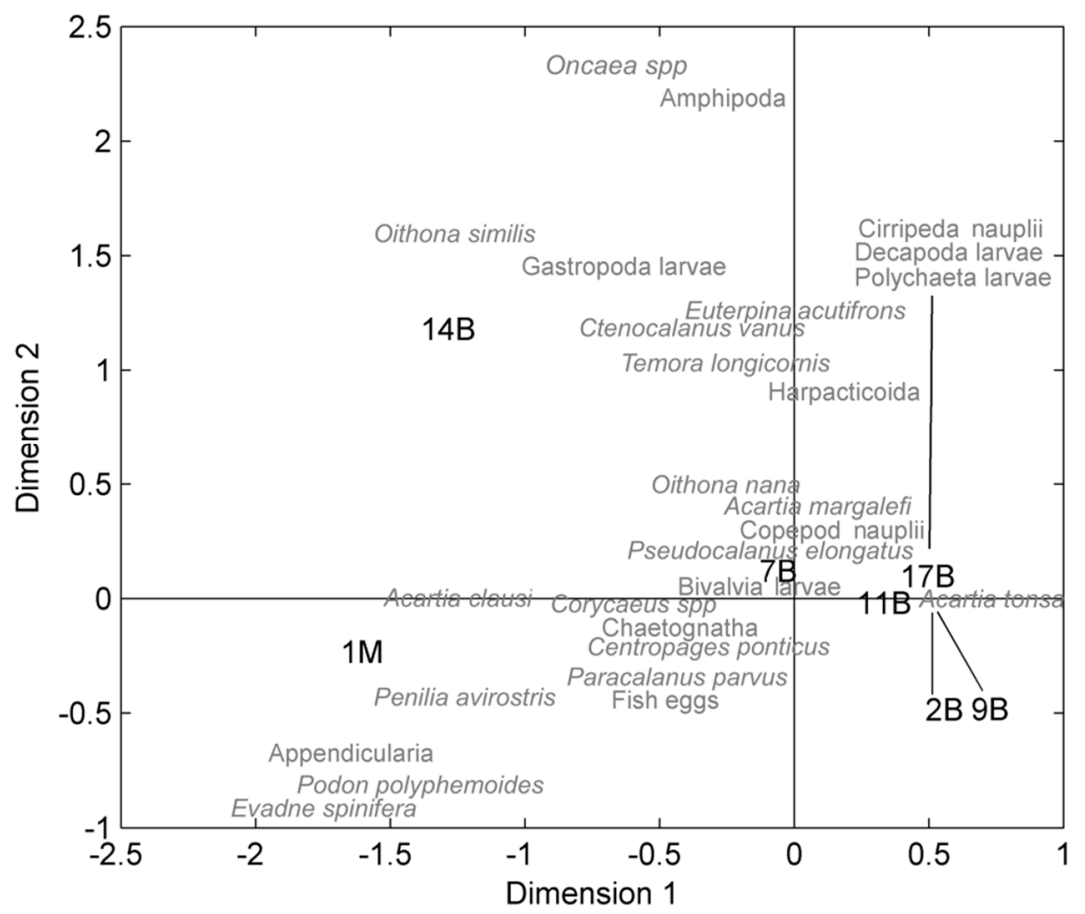

Figure 6. Results of the correspondence analysis (CA) performed on seven stations and total annual abundances (May 2003-April 2004). The first letter of each species' name corresponds to the actual position on the CA space. For enhanced readability, only species with relative abundance $>5 \%$ are shown. Stations B2 and B9 as well as Polychaeta larvae, Decapoda larvae, and Cirripeda nauplii species have been moved from their respective original positions, indicated by the black lines.

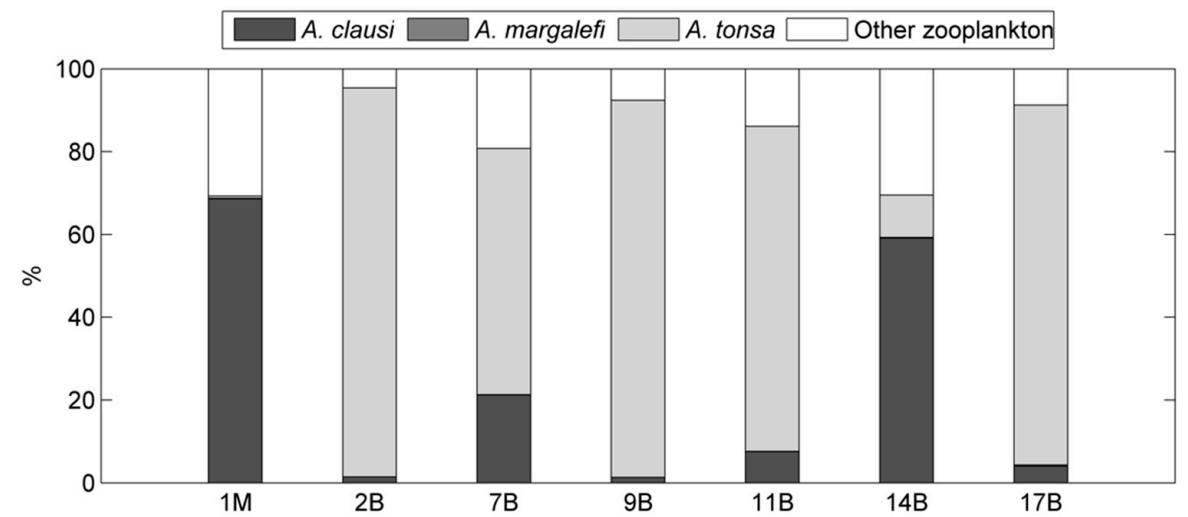

Figure 7. Relative abundance, station by station, of A. tonsa with respect to the other Acartia species and the remaining zooplankton during 2003-2004 period.

Data related to the last period 2014-2017 (DS4), though only seasonal, confirmed the presence and the dominance of three principal Acartia species inside the lagoon: A. margalefi, A. clausi and A. tonsa. A different distribution of these species along physical and trophic gradients was also found: A. margalefi coexisted with $A$. tonsa mainly in the intermediate lagoon areas (Figure 8). Both virtually disappeared at stations with marine features (Lido and PTF) where A. clausi instead dominated. $P$. latisetosa was found with very limited abundance in the inner lagoon stations (Inside, Marghera, and Fusina) only in May 2014 at 4 ind $\mathrm{m}^{-3}$ or less. 


\begin{tabular}{|lll|}
\hline May 2014 & Feb 2015 & \\
\hline Aug 2014 & May 2015 & Jul 2016 \\
\hline Oct 2014 & Nov 2016 \\
\hline
\end{tabular}

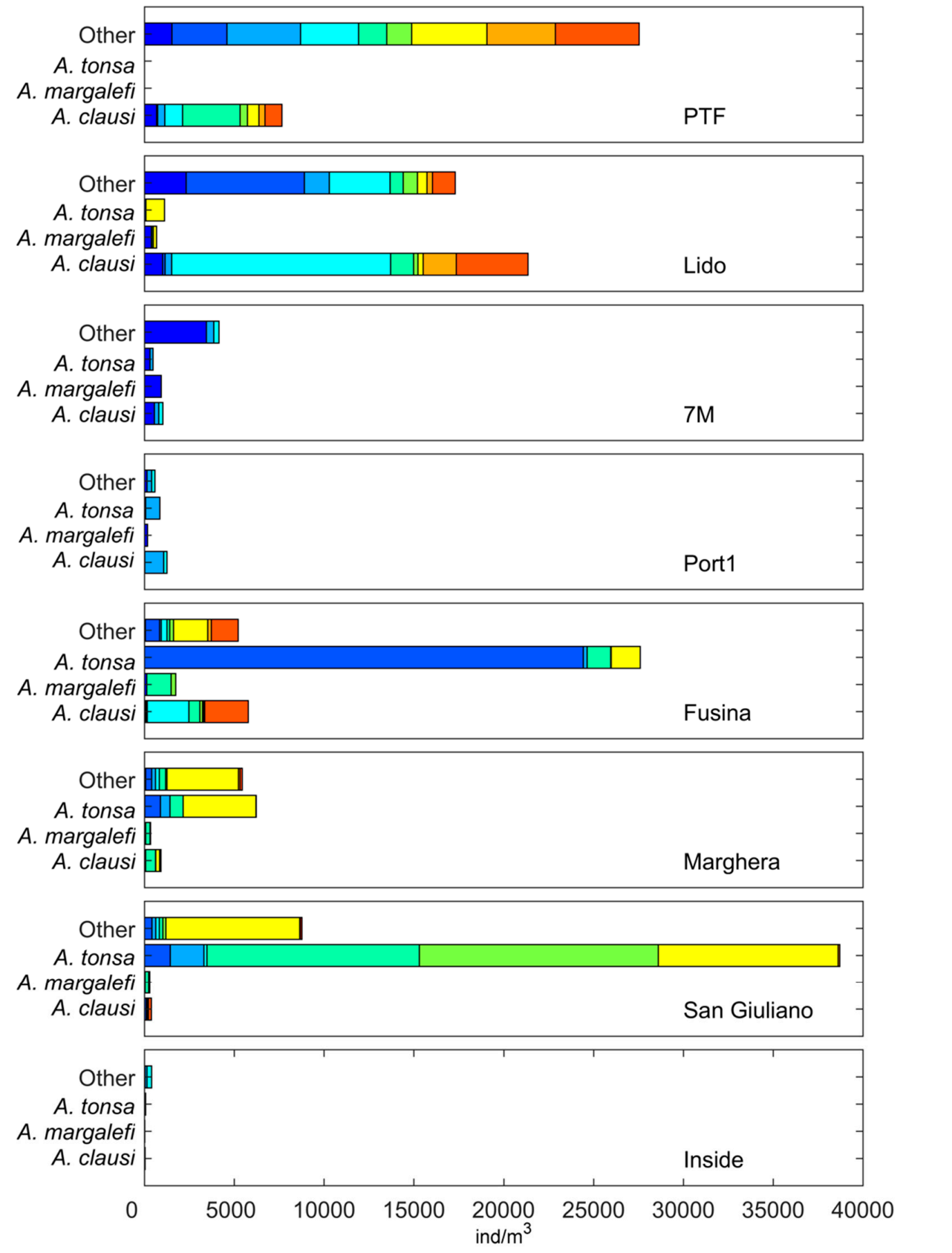

Figure 8. Seasonal relative abundance of $A$. tonsa with respect to other Acartia species and remaining zooplankton at stations for the 2014-2017 period. Data related to 7M, Port1, and inside refer only to May 2014, October 2014, and February 2015 sampling dates.

RDA analysis showed that the relative rank distribution of the most representative zooplankton species in the community changed over time and in space by comparing the periods before and after the arrival of $A$. tonsa. First of all, Figure 9 shows that much of the RAD shape was steeply dominated by the arrival of $A$. tonsa, especially in inner areas where the species reached maximum abundance values and exceeded those of the congeneric ones. A. clausi maintained the most representative relative abundance of the Acartia genus throughout the period prior to the arrival of $A$. tonsa and in all three considered areas (Figure 9). It maintained the same relative rank also in the following periods but only 
in the inlet areas. In the years following its appearance, $A$. tonsa replaced $A$. clausi in the intermediate and inner areas. P. latisetosa reached an important distribution rank only in the internal areas and in the pre- $A$. tonsa period, after which it could always be found on the low-rank curve tail both in spatial and temporal terms. A. margalefi, also with an important relative abundance, before the arrival of $A$. tonsa, especially in the most typically lagoon areas (intermediate and inner), fell in rank with the appearance of $A$. tonsa (D3), but then (D4) recovered in terms of presence and abundance mainly in the intermediate areas (Figure 9).

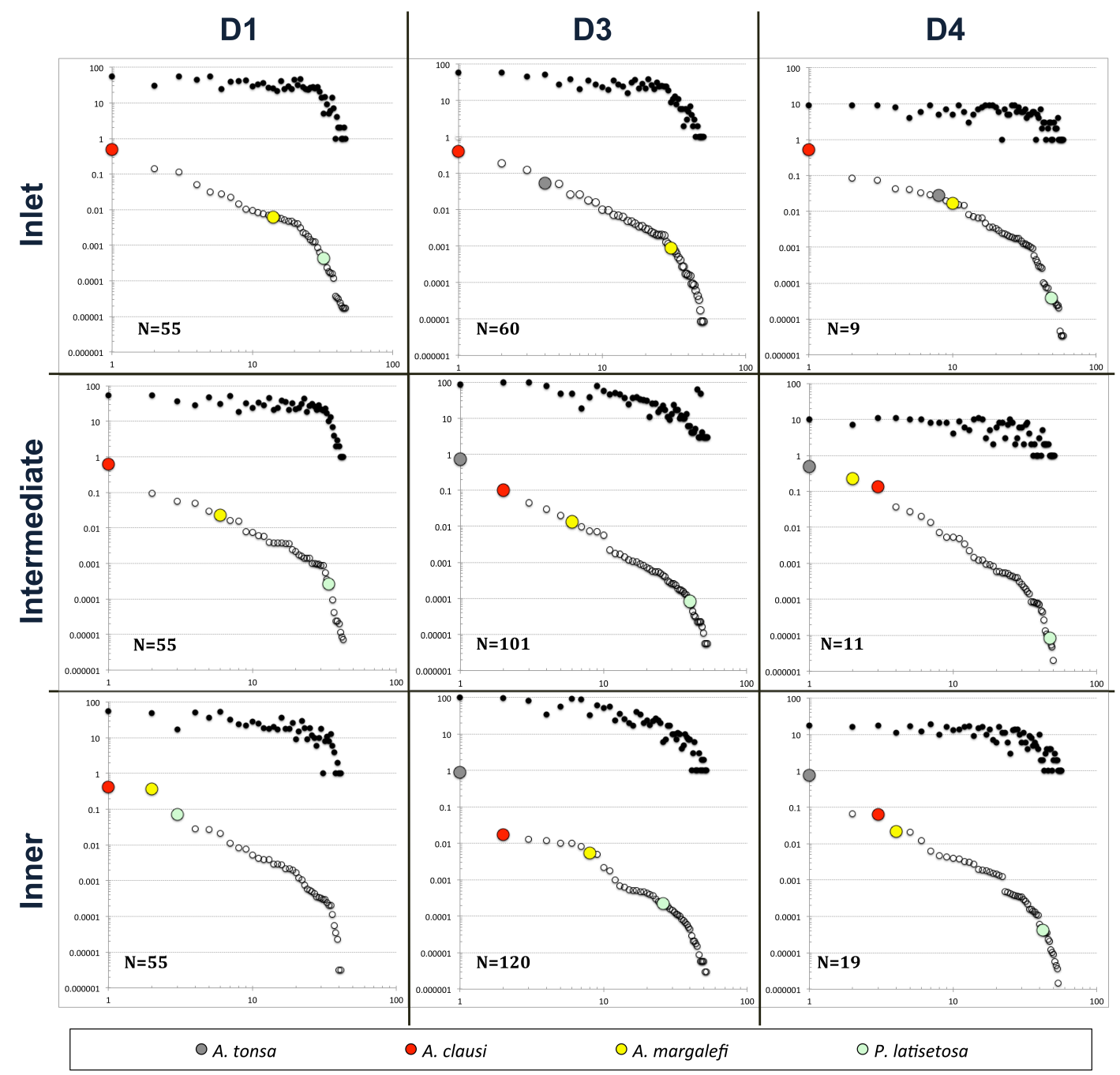

Figure 9. Rank abundance distribution (RAD) and occurrence of the zooplankton community of the Venice lagoon during the period of study (decade D1: 1975-1985, from data set DS1; decade D3: 1995-2005, from data set DS3; and recent period D4: 2005-2017, from data set DS4). The samples were lumped according to the three habitat types along a gradient from the mainland to the sea (see text). In every frame, the upper curve gives the ranked occurrence of each species in the lumped N samples; the Acartia species's relative ranks are highlighted along the lower RAD curve.

With an OMI analysis, we computed and tested niche parameters (Table 5) to describe marginality, tolerance, and, thus, the variability of responses of Acartia species to environmental variables as well as their possible niche overlap. Figure 10 shows the representation of the statistically significant species' realized niche position of Acartia species on the first factorial plane of the OMI analysis whose origin represents the average habitat conditions of the sampling area. The two first axes of the OMI analysis accounted for $81 \%$ of the marginality ( $69 \%$ for the first axis). As a consequence, subsequent graphs used only these two axes. Seventeen out of 66 taxa showed a significant deviation $(p<0.05)$ of 
their niche from the origin (whereas among the Acartiidae, only A. clausi was significant, $\mathrm{p}<0.01$ ) suggesting a significant influence of the environmental conditions for a relevant part of the community (Monte-Carlo krandtest, perm $=999$ ). Furthermore, the between-site analysis confirmed that the environmental gradient of sites (sea, inlet, intermediate, and inner) could be discriminated through the inhabiting zooplankton community (Monte-Carlo rtest, perm $=99, p<0.01$ ). In our case, the tendency of low values of marginality for Acartia species indicated that there was no significant difference between the average overall environmental conditions and those where the species were preferentially found. The niches of the three typical lagoon species, P. latisetosa, A. margalefi, and A. tonsa, gravitated around less salty and more trophic environments and also presented an evident overlap. Furthermore, A. tonsa and A. clausi, the latter having more neritic coastal characteristics, were equidistant from the average environmental conditions. Therefore, this showed a clear affinity, or the opposite, depending on the environment taken into consideration: coastal marine sites for A. clausi (sea and inlet in the chart) and lagoon for $A$. tonsa (intermediate and inner). In particular, $A$. tonsa had a low marginality and a high residual tolerance to environmental conditions, whereas A. clausi showed an opposite trend but was still relative low OMI values (Table 5). As for the other two typical lagoon species, A. margalefi had the lowest value of OMI, while P. latisetosa had the lowest RTol in comparison to the rest of the Acartia species (Table 5). This meant that A. clausi was greatly influenced by environmental conditions, whereas $P$. latisetosa seemed to poorly depend on unconsidered environmental parameters (e.g., POC). Instead, A. tonsa showed wider potential ecological tolerance. In general, most common habitat conditions covered by the sampling units corresponded to the ubiquitous or generalist species. In contrast, specialists, which deviated from these general habitat conditions, demonstrated high OMI values, as in the case of P. latisetosa with respect to the other two lagoon congeners. Tol values showed a high correlation and dependence of $P$. latisetosa on environmental variables, while $A$. tonsa, with its high RTol, showed a greater adaptability to the variations of the ecosystem in which it gravitated. A. margalefi had the lowest OMI and Tol values.

Table 5. Niche parameters of the 20 most abundant zooplankton taxa in the Lagoon of Venice during 2014-2017 (outlying mean index (OMI) analysis). The inertia of each species, OMI, the tolerance index (Tol), and the residual tolerance index (RTol) are indicated. The last column (p) represents the percentage of random permutations (out of 1000) that yielded a higher value than the observed OMI (significant cases are in bold, $\mathrm{p}<0.05$ ).

\begin{tabular}{cccccc}
\hline Species & Inertia & OMI & Tol & RTol & p \\
\hline Acartia tonsa & 12.76 & 2.80 & 1.35 & 8.61 & 0.497 \\
Acartia clausi & 9.37 & 3.13 & 2.08 & 4.15 & $\mathbf{0 . 0 1 2}$ \\
Paracalanus parvus & 11.78 & 3.91 & 2.58 & 5.28 & $\mathbf{0 . 0 3 4}$ \\
Decapoda larvae & 19.07 & 11.62 & 5.09 & 2.36 & 0.620 \\
Acartia margalefi & 6.37 & 1.66 & 0.90 & 3.80 & 0.880 \\
Podonidae & 7.09 & 2.36 & 0.30 & 4.43 & 0.818 \\
Penilia avirostris & 8.46 & 5.69 & 0.49 & 2.28 & $\mathbf{0 . 0 3 0}$ \\
Appendicularia & 9.84 & 3.35 & 2.38 & 4.09 & 0.567 \\
Centropages ponticus & 8.07 & 2.95 & 1.29 & 3.82 & 0.214 \\
Ascidiacea larvae & 14.44 & 10.33 & 1.55 & 2.56 & 0.728 \\
Echinodermata larvae & 10.35 & 6.66 & 0.79 & 2.91 & $\mathbf{0 . 0 1 5}$ \\
Oithona similis & 10.68 & 6.38 & 0.93 & 3.36 & $\mathbf{0 . 0 1 1}$ \\
Nauplii copepoda & 7.95 & 1.93 & 0.90 & 5.12 & 0.819 \\
Evadne nordmani & 7.08 & 5.52 & 0.21 & 1.35 & 0.849 \\
Harpacticoida & 13.32 & 1.63 & 2.48 & 9.22 & 0.802 \\
Clausocalanus spp. & 12.91 & 8.93 & 0.84 & 3.15 & 0.268
\end{tabular}

${ }^{1}$ P. latisetosa does not fall within the 20 higher ranks. 


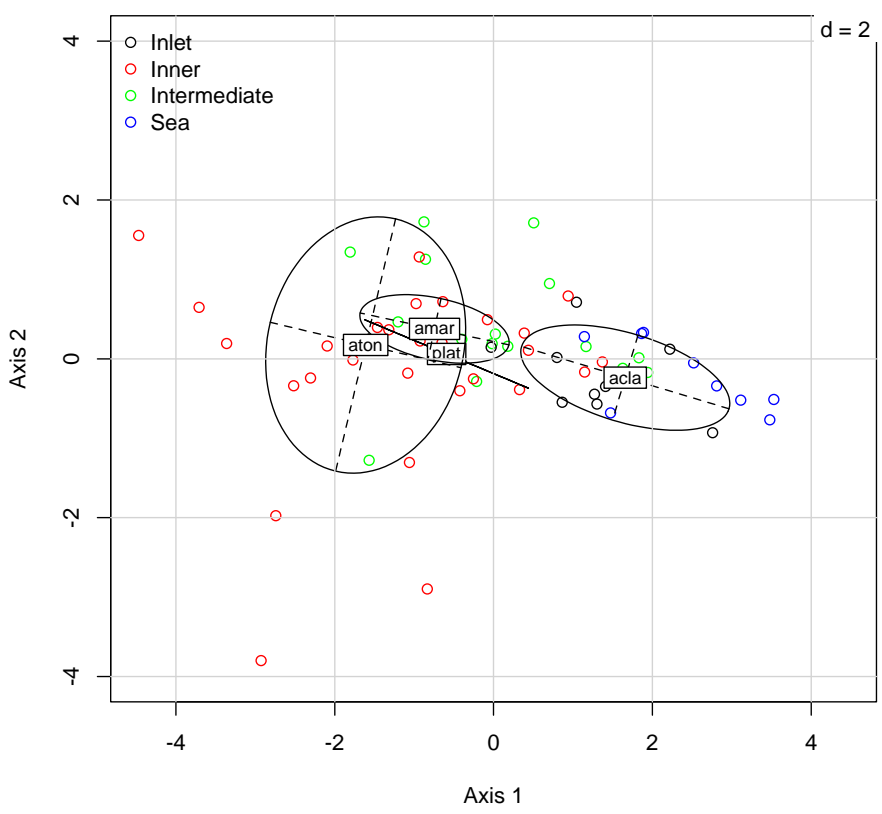

Figure 10. OMI analysis. Realized niche position of Acartia species in the Lagoon (2014-2017 dataset). The site scores are projected on the same first two axes of the OMI analysis, and the habitat type is highlighted (Labels: acla $=$ A. clausi; aton $=A$. tonsa $;$ plat $=$ P. latisetosa $;$ and amar $=A$. margalefi) .

\section{Discussion}

The occurrence of NIS is increasing in marine and estuarine systems. Among the 955 new taxa reported for the Mediterranean Sea, 42 are planktonic copepods [47]. Their invasive behaviour has been recognized as one of the major threats to the conservation of the biodiversity and the functioning of marine ecosystems [48-50]. A. tonsa dated its first appearance in the Venice lagoon in 1992. Since then, it never disappeared, and it is now present throughout the year and dominant with the exception of colder months. The species is widespread throughout the lagoon with significant abundance except for the areas closer to the tidal inlets, where the trophic condition is lowered and the hydro-chemical characteristics become less favourable to the species. In the Venice lagoon, A. tonsa is currently considered a stabilized species. The most plausible hypotheses about the introduction of this species are that it was brought into the outer port area thanks to its ability to produce resting eggs, then via ballast water from ships [51-53], or released by aquaculture, fisheries, or pet industries [54].

Our study showed how the trophic conditions of the lagoon system were (and still are) the main factors that influenced its adaptive success. Unlike the other main species present within the lagoon zooplankton communities, $A$. tonsa seems strongly dependent on trophic conditions, as it is positively correlated with nutrients, $\mathrm{Chl} a, \mathrm{POC}$, and phytoplankton concentrations. The favourable environmental conditions that the species found in 1992, fundamentally characterized by high habitat trophic levels [55], are congruent with our current findings and to the ecological characteristics of the species $[8,15,56]$. This allowed the settlement of $A$. tonsa in the Lagoon of Venice.

Much of the available knowledge about zooplankton communities of the Venice lagoon, mainly copepods, derives from studies along the physical and trophic gradient of the northern lagoon. In this area, Acartia genus usually represents a quantitative, important component of the zooplankton communities. It shows spatial and seasonal segregation patterns associated with the hydrological conditions, the seasonal variability, and the trophic status and pollution of the water $[31,57,58]$.

Comparison of the whole zooplankton community throughout the four decades and the different habitats highlighted that in the Venice lagoon, before the arrival of A. tonsa, the genus Acartia dominated the copepod community with P. latisetosa and $A$. margalefi usually found in the innermost and intermediate parts of the lagoon, respectively. In particular, in the more internal areas, $A$. margalefi and P. latisetosa ranked second and third, respectively, in terms of presence and abundance, though 
P. latisetosa greatly diminished in significance in the intermediate areas. The dominant species A. clausi ranked always first, mainly in the coastal area. This picture instead has been profoundly modified with the passage from the first analysed decade (i.e., before the invasion of $A$. tonsa) to the following ones. In fact, the current scenario shows, again, the Acartia species among the dominant species of the entire lagoon zooplankton community, and it is always organized along a spatial gradient determined by salinity and trophic conditions but with modified rankings in the different considered areas. A. clausi no longer dominates all the considered sub-basins, except for the inlet area where it is, again, the most representative species both in space and in time. P. latisetosa, whose presence and dominance were already weak in the intermediate areas, further lost importance in the inner areas and virtually disappeared except in spring 2014. Very little abundance of the species was observed only in the internal channels of the lagoon (Inside, Marghera, and Fusina stations). We argue this could either be due to its segregation in more confined and not yet investigated areas or to the occupation of its original habitat by A. tonsa. In the presence of a large salinity and trophic range, the Acartia species coexist in time with a strong spatial segregation that shows $A$. clausi limited to the inlet and coastal areas, $A$. margalefi in the intermediate area, and partly overlapping with $A$. tonsa that dominates in the innermost areas.

During the second decade (1995-2005), coinciding with the first phase of stabilization of the species after its first occurrence dated 1992, A. tonsa seems to clearly supplant the A. clausi and A. margalefi congeners in the intermediate and mostly internal areas, whereas occupation of $A$. clausi near the lagoon mouths failed. It is interesting to note that, in more recent times (2005-2017), A. margalefi appears to be recovering its original ranking, returning to coexist with $A$. tonsa in the intermediate areas. As reported in other Adriatic lagoons $[59,60]$, the arrival of $A$. tonsa may have caused the disappearance or drastic decrease of congeneric species, and the current coexistence of $A$. tonsa and A. margalefi is probably favored by a greater resilience of the latter as well as a return to more favorable environmental conditions always for the latter (decline in nutrient concentration and increase in ecological status) [61].

Therefore, among the main factors that seem to have favoured the adaptive success of $A$. tons $a$ compared to its congeners, we can ascribe the deterioration of the environmental conditions during the 1970s and the 1980s to when the lagoon of Venice was affected by abnormal inputs of pollutants and trophic loadings, mainly phosphorus and nitrogen compounds, which induced massive macroalgae growth (Ulva rigida C. Agardh, 1823) whose decomposition in summer led to frequent dystrophic crises [62-65]. Later, during the 1990s, the Lagoon of Venice experienced significant changes in both primary production and trophic conditions. In particular, Ulva coverage rapidly declined [64], mainly because of climatic changes and the increase of sediment resuspension and sedimentation [66]. As a consequence, since the end of 1980s and through the 1990s, the presence patterns of Acartia species also changed the mesozooplankton composition of the lagoon.

Within this scenario, and knowing that $A$. tonsa can tolerate low dissolved oxygen concentrations and adapt well to hypoxia $[67,68]$, we hypothesized that the hypoxia and hypertrophy in the inner lagoon area could not have hindered the settlement of $A$. tons $a$ whose adaptive success almost seemed to have benefited. Our results seem to support the hypothesis that, after a first important collapse of $A$. margalefi coinciding with the deterioration of environmental conditions and with the advent of $A$. tonsa, the first remained segregated in the intermediate areas of the lagoon, leaving $A$. tons $a$ to the innermost ones. Given the niche overlap that emerged from the OMI analysis, it is quite clear that competition for the same resources may be one of the main factors affecting the coexistence of the different Acartia in the same area, and that the observed decline in abundance of P. latisetosa and A. margalefi could be linked to changes in environmental conditions during the 1980s that favored A. tonsa development. Acartia genus is known to have both herbivorous and omnivorous feeding habits, depending on the environmental resources [69], although little knowledge exists about the nutritional requirements of $A$. margalefi [70]. The available studies report that $P$. latisetosa probably has an omnivorous or detritivorous diet just like $A$. tonsa [71]. Our analyses suggest for these two 
congeners a stricter dependence on the considered trophic variables resulting in a stronger competition for food with $A$. tonsa.

Therefore, change in distribution and size of the populations of A. margalefi and P. latisetosa occurred from the second half of the 1980s to the present. This probably depended on the success of recruitment that, in turn, could have been influenced by the system's trophic conditions but also, consequently, by the presence of effective competitors such as $A$. tonsa, which are also known to be an active predator of early larval forms. Competition with other copepods, especially congeneric, appears to be the main documented impact of $A$. tonsa (e.g., $[4,51,52,72,73])$ besides being known that A. tonsa species may coexist with indigenous Acartiidae (e.g., [6]) or exclude them by competition [5], as suggested in some Mediterranean systems $[57,59,60]$, where it seems that $A$. margalefi and $A$. clausi are not able to settle down in large populations in areas colonized by $A$. tonsa $[59,74]$.

This may indicate that large-scale changes, as well as a biotic interactions with the species and mainly with the "new" species $A$. tonsa, might be responsible for the evolution in the lagoon of Venice of different dominant copepod associations with respect to the past. The triggering phenomenon seems to have been the anthropic action on such a delicate and dynamic ecosystem, whose impact $A$. tonsa took advantage of.

Currently $A$. tonsa dominates the intermediate and internal areas of the lagoon, and it reaches the highest population abundance to the detriment of the indigenous congener species. The process, initially favored by the negative effect of changes in environmental conditions, worsened because a clear niche overlap emerged, which was confirmed by our study, in particular between $A$. tons $a$ and A. margalefi with $A$. tonsa benefiting from the point of view of trophic resources. The extent of its area of distribution in the lagoon confirms its euryhaline species characteristics and its excellent adaptability to instantaneous variations in habitat conditions. At present, the lagoon is oligo-mesotrophic over a great part of its surface [61] and dominated by areas classified as polyhaline (18 to 30 salinity) that correspond to the optimal development of $A$. tonsa (salinity ranging from 15 to 22), where the lowest salinities limit its egg production [75].

The adaptive success of $A$. tonsa with respect to its congener in the Lagoon of Venice corroborate the findings that $A$. tons $a$ is an opportunistic, tolerant species that can take advantage of eutrophic/impacted ecosystems $[4,9,31,76,77]$ and invade them.

Restriction of $A$. tonsa distribution offshore seems mainly influenced by food availability and less by the salinity. In the Lagoon of Venice, $A$. tonsa can sustain the high energy requirements. Moreover, competition with true marine copepods is reduced because of the habitat selection that takes place along the lagoon-sea gradient. It is also probable that the spatial width and heterogeneity of the Venetian lagoon favored and allowed the gradual recovery of the community of $A$. margalefi in recent years, which we observed in the present work. Succumbing to the highly competitive level of the alien $A$. tonsa, $A$. margalefi seems to have rediscovered a niche that does not completely overlap that of A. tonsa right along the saline and trophic gradient that exists in the lagoon.

The reports of new NIS in the Venice lagoon-the copepods Pseudiaptomus marinus Sato (1913), Oithona davisae Ferrari F.D. and Orsi (1984), and ctenophore Mnemiopsis leidyi A. Agassiz (1865) [53,78] —are also very recent. The latter, reported for the first time in the lagoon in 2016, is still present throughout the year, and its strong predator characteristics on the planktonic component [78] could revolutionize again the structure of the Acartia genus and in general of the zooplankton communities in a few years. Copepods are important components of the pelagic food web, as they are themselves food resources for numerous bentho-pelagic invertebrates and planktivorous juveniles of fishes. The advent of new species capable of competing for the same resources, as M. leidyi, could trigger a process at the base of the trophic levels that would affect the highest ones. So, the story of an invasion could therefore not have ended here. 


\section{Conclusions}

The Lagoon of Venice has been recognized as a hot spot for the introduction of nonindigenous species [25]. Several anthropogenic factors (industrial and urban pollution, mariculture, shipping, and tourism) as well as environmental stressors (e.g., warming) concurred to make this ecosystem ideal for invasion as in other estuaries and coastal areas of the Mediterranean. In this work, four datasets of mesozooplankton were examined, with particular emphasis on Acartiidae and the alien species A. tonsa. The first dataset, dated 1975-1980, was used as a term of comparison before $A$. tonsa settlement. The second dataset (during 1997-2002) was used to investigate the seasonal cycle and temporal trends. The third dataset (2003-2004) was used to underpin the spatial variability of abundance and species composition, and the last dataset (the recent period until 2017) was used to confirm the presence of $A$. tonsa several years later. The selected trend test on $A$. tonsa abundance did not point out significant overall increases in the period 1997-2002, but it did point out increases in one single station (the most eutrophic one). This may be suggestive that the population has reached a mature stage of colonization in the lagoon. The annual cycle showed maxima in the warm season (mostly July) and negligible abundances in the cold season. Spatial distribution of $A$. tonsa was found to be significantly, positively associated with temperature, phytoplankton, POC, chlorophyll $a$, and counter gradient of salinity, which confirmed that $A$. tonsa was an opportunistic tolerant species that could take advantage of eutrophic ecosystems. This would seem to have occurred at the expense of the previously dominant species $A$. margalefi and P. latisetosa, which clearly declined in abundance over the last years. While $P$. latisetosa almost disappeared, $A$. margalefi was not completely excluded. Stations inside the lagoon showed similar species compositions remarkably different from the station in the outer shelf, which was more representative of coastal conditions and dominated by A. clausi. In 2014-2017, A. tonsa was found to be still one of the dominant Acartia species in the lagoon.

Zooplankton is known to be particularly sensitive to environmental changes, whether resulting from natural or anthropogenic forcing [79-82]. The interaction between anthropogenic activity, climate change, and plankton communities, focusing on systematic changes in plankton community structure, abundance, distribution, and phenology over recent decades, is a key global issue as well as the potential socioeconomic impacts of these changes [83]. In environments of relentless evolution such as the Lagoon of Venice, monitoring the ecological dynamics of species is of the utmost importance. In particular, continuous modifications in zooplankton assemblages in response to anthropogenic and environmental stressors must be considered. Ongoing plankton monitoring in the LTER site of the Lagoon of Venice will act as sentinel research to identify future changes in this complex, heavily impacted ecosystem and its related food web.

Author Contributions: E.C. contributed substantially to the study's conceptualization, data acquisition, analysis, and to the original draft preparation; M.P. contributed to recent data acquisition and analysis and to the review and editing; and A.B. contributed substantially to statistical analyses and to the review of the manuscript. All authors approved the final submitted manuscript.

Funding: This work was supported by the LIFE-WATERS Program, EC-sponsored, for the two-year period 1997-1999. The data set 2002-2003 was collected within the framework of the "Integrazione delle Conoscenze del Sistema Ecologico Lagunare (ICSEL)" project, promoted by the Venice Water Authority (Magistrato alle Acque) through Servizio Ambiente-Consorzio Venezia Nuova, while the dataset 2014-2017 derived from the ADRIATIC IPA BALMAS (Ballast Water Management System for Adriatic Sea Protection) Project and from the LTER.

Acknowledgments: The authors acknowledge Thetis S.p.A. for providing the environmental data during 2003-2004 period and the CNR colleague F. Acri for his help in carrying out biochemical analyses. We wish to thank F. Bernardi Aubry, M. Bastianini, S. Finotto, A. Schröder, S. Pasqual, L. Dametto, and M. Casula for the fieldwork technical support during sampling and the crew of the M/B “Litus” G. Zennaro, D. Penzo, and M. Penzo.

Conflicts of Interest: The authors declare no conflict of interest.

\section{References}

1. IMO (International Maritime Organization). Global Ballast Water Management Project: The Problem. Available online: http://globallast.imo.org/index.asp?page=problem.htm\&menu=true (accessed on 7 May 2019). 
2. Gaudy, R.; Vinas, M. Premiere signalisation en Méditerrannée du copepode pélagique Acartia tonsa. Rapp. Comm. Int. Mer Mediterr. 1985, 219, 227-229.

3. Seuront, L. First record of the calanoid copepod Acartia omorii (Copepoda: Calanoida: Acartiidae) in the southern bight of the North Sea. J. Plankton Res. 2005, 27, 1301-1306. [CrossRef]

4. David, V.; Sautour, B.; Chardy, P. Successful colonization of the calanoid copepod Acartia tonsa in the oligo mesohaline area of the Gironde estuary (SW France) Natural or anthropogenic forcing? Estuar. Coast. Shelf Sci. 2007, 71, 429-442. [CrossRef]

5. Belmonte, G.; Potenza, D. Biogeography of the family Acartiidae (Calanoida) in the Ponto Mediterranean Province. Hydrobiologia 2001, 453, 171-176. [CrossRef]

6. Lakkis, S. Coexistence and competition within Acartia (Copepoda, Calanoida) congeners from Lebanese coastal water: Niche overlap measurements. In Ecology and Morphology of Copepods, Hydrobiologia; Ferrari, F.D., Bradley, B.P., Eds.; Kluwer Academic Publishers: Brussels, Belgium, 1994; Chapter 292-293; pp. 481-490.

7. Hoffmeyer, M.S. Decadal change in zooplankton seasonal succession in the Bahía Blanca Estuary, Argentina, following introduction of two zooplankton species. J. Plankton Res. 1994, 26, 1-9. [CrossRef]

8. Durbin, E.G.; Durbin, A.G.; Smayda, T.J.; Verity, P.G. Food limitation of production by adult Acartia tonsa in Narragansett bay, Rhode Island. Limnol. Oceanogr. 1983, 28, 1199-1213. [CrossRef]

9. Brylinski, J.M. Report on the presence of Acartia tonsa Dana (Copepoda) in the harbour of Dunkirk (France) and its geographical distribution in Europe. J. Plankon Res. 1981, 3, 255-260. [CrossRef]

10. Gruszka, P. The River Odra Estuary as a Gateway for Alien Species Immigration to the Baltic Sea Basin. Acta Hydrochim. Hydrobiol. 1999, 27, 374-382. [CrossRef]

11. Farabegoli, A.; Ferrari, I.; Manzoni, C.; Pugnetti, A. Prima segnalazione nel Mare Adriatico del copepode calanoide Acartia tonsa. Nov. Thalass. 1989, 10, 207-208.

12. Quarta, S.; Belmonte, G.; Caroppo, C.; Pacifico, P.; Petraroli, P. Zooplankton seasonal trend in the Lesina and Varano Lagoons (Apulian coast of Italy). Oebalia 1992, 17, 403-404.

13. Comaschi, A.; Cavalloni, B. Variabilità stagionale dello zooplancton nella Palude della Rosa (laguna di Venezia bacino settentrionale). SITE 1995, 16, 75-78.

14. Durbin, A.G.; Durbin, E.G. Standing stock and estimated production rates of phytoplankton and zooplankton in Narragansett Bay, Rhode Island. Estuaries 1981, 4, 24-41. [CrossRef]

15. Roman, M.R. Utilization of detritus by the copepod Acartia tonsa. Limnol. Oceanogr. 1984, 5, 949-959. [CrossRef]

16. Paffenöfer, G.A.; Stearn, D.E. Why is Acartia tonsa (Copepoda: Calanoida) restricted to nearshore environment? Mar. Ecol. Prog. Ser. 1988, 42, 33-38. [CrossRef]

17. Zhang, J.; Ianora, A.; Wu, C.; Pellegrini, D.; Esposito, F.; Buttino, I. How to increase productivity of the copepod Acartia tonsa (Dana): Effects of population density and food concentration. Aquac. Res. 2015, 46, 2982-2990. [CrossRef]

18. Tagliapietra, D.; Sigovini, M.; Volpi Ghirardini, A. A review of terms and definitions to categorise estuaries, lagoons and associated environments. Mar. Freshw. Res. 2009, 60, 497-509. [CrossRef]

19. Tagliapietra, D.; Zanon, V.; Frangipane, G.; Umgiesser, G.; Sigovini, M. Physiographic zoning of the Venetian Lagoon. In Scientific Research and Safeguarding of Venice, 2010; CORILA: Venice, Italy, 2007; pp. 161-164.

20. Occhipinti Ambrogi, A.; Marchini, A.; Cantone, G.; Castelli, A.; Chimenz, C.; Cormaci, M.; Froglia, C.; Furnari, G.; Gambi, M.C.; Giaccone, G.; et al. Alien species along the Italian coasts: An overview. Biol. Invasion 2011, 13, 215-237. [CrossRef]

21. Keppel, E.; Sigovini, M.; Tagliapietra, D. A new geographical record of Polycera hedgpethi Er. Marcus, 1964 (Nudibranchia: Polyceridae) and evidence of its established presence in the Mediterranean Sea, with a review of its geographical distribution. Mar. Biol. Res. 2012, 8, 969-981. [CrossRef]

22. Sfriso, A.; Campolin, M.; Sfriso, A.; Buosi, A.; Facca, C. Change of aquatic flora and vegetation in ecological gradients from the lagoon inlets to some fishing ponds of the Venice lagoon. Biol. Mar. Mediterr. 2012, 19, 53-56.

23. Sfriso, A.; Facca, C. Annual growth and environmental relationships of the invasive species Sargassum muticum and Undaria pinnatifida in the lagoon of Venice. Estuar. Coast. Shelf Sci. 2013, 129, 162-172. [CrossRef]

24. Tagliapietra, D.; Keppel, E.; Sigovini, M. First record of the colonial ascidian Didemnum vexillum Kott, 2002 in the Mediterranean: Lagoon of Venice (Italy). BioInvasions Rec. 2012, 1, 247-254. [CrossRef] 
25. Marchini, A.; Galil, B.S.; Occhipinti Ambrogi, A. Recommendations on standardizing lists of marine alien species: Lessons from the Mediterranean Sea. Mar. Pollut. Bull. 2015, 101, 267-273. [CrossRef] [PubMed]

26. Solidoro, C.; Pastres, R.; Cossarini, G.; Ciavatta, S. Seasonal and spatial variability of water quality parameters in the lagoon of Venice. J. Mar. Syst. 2004, 51,7-18. [CrossRef]

27. Gačić, M.; Kovačević, V.; Mancero Mosquera, I.; Mazzoldi, A.; Cosoli, S. Water fluxes between the Venice Lagoon and the Adriatic Sea. In Flooding and Environmental Challenges for Venice and Its Lagoon: State of Knowledge; Fletcher, C.A., Spencer, D.T., Eds.; Cambridge University: Cambridge, UK, 2005; pp. 431-444.

28. Cucco, A.; Umgiesser, G. Modelling the Venice Lagoon residence time. Ecol. Model. 2006, 193, 34-51. [CrossRef]

29. Ravera, O. The Lagoon of Venice: The result of both natural factors and human influence. J. Limnol. 2000, 59, 19-30. [CrossRef]

30. Solidoro, C.; Bandelj, V.; Aubry Bernardi, F.; Camatti, E.; Ciavatta, S.; Cossarini, G.; Facca, C.; Franzoi, P.; Libralato, S.; Melaku Canu, D.; et al. Response of Venice Lagoon Ecosystem to Natural and Anthropogenic Pressures over the Last 50 Years. In Coastal Lagoons Critical Habitats of Environmental Change; Kennish, M., Paerl, H.W., Eds.; CRC Press: Boca Raton, FL, USA, 2010; pp. 483-511.

31. Bianchi, F.; Acri, F.; Bernardi Aubry, F.; Berton, A.; Boldrin, A.; Camatti, E.; Cassin, D.; Comaschi, A. Can plankton communities be considered as bio indicators of water quality in the Lagoon of Venice? Mar. Pollut. Bull. 2003, 46, 964-971. [CrossRef]

32. Bianchi, F.; Socal, G.; Alberighi, L.; Cioce, F. Cicli nictemerali dell'ossigeno disciolto nel bacino centrale della laguna di Venezia. Biol. Mar. Mediterr. 1996, 3, 628-630.

33. Socal, G.; Bianchi, F.; Alberighi, L. Effects of thermal pollution and nutrient discharges on a spring phytoplankton bloom in the industrial area of the lagoon of Venice. Vie Milieu 1999, 49, 19-31.

34. Harris, R.P.; Wiebe, P.H.; Lenz, J.; Skjoldal, H.R.; Huntley, M. ICES Zooplankton Methodology Manual; Academic Press: Cambridge, MA, USA, 2000; p. 684.

35. Camatti, E.; Ferrari, I. Mesozooplankton. In Metodologie di Studio Del Plancton Marino; Socal, G., Buttino, I., Cabrini, M., Mangoni, O., Penna, A., Totti, C., Eds.; Manuali e Linee Guida: Ispra, Italy, 2010; Volume 56, pp. 489-506.

36. Throndsen, J. Preservation and storage. In Phytoplankton Manual; Sournia, A., Ed.; UNESCO: Paris, France, 1978.

37. Utermöhl, H. Zur Vervollkommnung der quantitativen Phytoplankton Methodik. Int. Ver. Theor. Angew. Limnol. 1958, 9, 1-38. [CrossRef]

38. Zingone, A.; Honsell, G.; Marino, D.; Montresor, M.; Socal, G. Fitoplankton. Nov. Thalass. 1990, 11, $183-198$.

39. EPA (Environmental Protection Agency). Methods for Determination of Chemical Substances in Marine and Estuarine Environmental Matrices, 2nd ed.; EPA: Cincinnati, OH, USA, 1997.

40. IRSA (Istituto di Ricerca sulle Acque). Metodi di Analisi Per Acque di Mare. Quad. Ist. Ric. Acque 1997, 59, 570-571.

41. Hirsch, R.M.; Slack, J.R.; Smith, R.A. Techniques of trend analysis for monthly water quality data. Water Resour. Res. 1982, 18, 107-121. [CrossRef]

42. Kendall, M.G. Rank Correlation Methods, 4th ed.; Charles Griffin: London, UK, 1975.

43. Legendre, P.; Legendre, L.F. Numerical Ecology, 3rd ed.; Elsevier: Amsterdam, The Netherlands, 2012; Volume 24, p. 1006.

44. Davis, J.C. Statistics and Data Analysis in Geology, 3rd ed.; Wiley, J.S., Ed.; Wiley: Hoboken, NJ, USA, 1986; p. 646.

45. Dolédec, S.; Chessel, D.; Gimaret-Carpentier, C. Niche separation in community analysis: A new method. Ecology 2000, 81, 2914-2927. [CrossRef]

46. Sen, P.K. Estimates of the regression coefficient based on Kendall's Tau. J. Am. Stat. Assoc. 1968, 63, 1379-1389. [CrossRef]

47. Zenetos, A.; Gofas, S.; Verlaque, M.; Cinar, M.E.; Garcia Raso, J.E.; Bianchi, C.N.; Morris, C.; Azzurro, E.; Bilecenoglu, M.; Froglia, C.; et al. Alien species in the Mediterranean Sea by 2010. A contribution to the application of European Union's Marine Strategy Framework Directive (MSFD). Part I. Spatial distribution. Mediterr. Mar. Sci. 2010, 11, 381-493. [CrossRef]

48. Carlton, J.T. Biological invasions and cryptogenic species. Ecology 1996, 77, 1653-1655. [CrossRef]

49. Ruiz, G.M.; Fofonoff, P.; Hines, A. Non- indigenous species as stressors in estuarine and marine communities: Assessing invasion impacts and interactions. Limnol. Oceanogr. 1999, 44, 950-972. [CrossRef] 
50. Mack, R.N.; Simberloff, D.; Lonsdale, W.M.; Evans, H.; Clout, M.; Bazzaz, F.A. Biotic invasions: Causes, epidemiology, global consequences and control. Ecol. Appl. 2000, 10, 689-710. [CrossRef]

51. Gubanova, A. Occurrence of Acartia tonsa Dana in the Black Sea. Was it introduced from the Mediterranean? Mediterr. Mar. Sci. 2000, 1, 105-109. [CrossRef]

52. Gubanova, A.; Altukhova, D.; Stefanova, K.; Arashkevichc, E.; Kamburskad, L.; Prusovaa, I.; Svetlichnya, L.; Timoftee, F.; Uysalfand, Z. Species composition of Black Sea marine planktonic copepods. J. Mar. Syst. 2014, 135, 44-52. [CrossRef]

53. Vidjak, O.; Bojanić, N.; de Olazabal, A.; Benzi, M.; Brautović, I.; Camatti, E.; Hure, M.; Lipej, L.; Lučić, D.; Pansera, M.; et al. Zooplankton in Adriatic port environments: Indigenous communities and non-indigenous species. Mar. Pollut. Bull. 2008. [CrossRef]

54. Ruiz, G.M.; Carlton, J.T.; Grosholz, E.D.; Hines, A.H. Global invasions of marine and estuarine habitats by non-indigenous species: Mechanisms, extent and consequences. Am. Zool. 1997, 37, 621-632. [CrossRef]

55. Comaschi, A.; Acri, F.; Alberghi, L.; Bastianini, M.; Bianchi, F.; Cavalloni, B.; Socal, G. Presenza di Acartia tonsa (Copepoda: Calanoida) nella laguna di Venezia. Biol. Mar. Mediterr. 1994, 1, 273-274.

56. Bandelj, V.; Socal, G.; Park, Y.S.; Lek, S.; Coppola, J.; Camatti, E.; Capuzzo, E.; Milani, L.; Solidoro, C. Analysis of multitrophic plankton assemblages in the lagoon of Venice. Mar. Ecol. Prog. Ser. 2008, 368, 23-40. [CrossRef]

57. Comaschi, A.; Acri, F.; Bianchi, F.; Bressan, M.; Camatti, E. Temporal changes of species belonging to Acartia genus (Copepoda: Calanoida) in the northern basin of the Venice lagoon. Boll. Mus. Civ. Stor. Nat. Venezia 2000, 50, 189-193.

58. Camatti, E.; Comaschi, A.; Coppola, J.; Milani, L.; Minocci, M.; Socal, G. Analisi dei popolamenti zooplanctonici nella laguna di Venezia dal 1975 al 2004. Biol. Mar. Mediterr. 2006, 13, 46-53.

59. Sei, S.; Ferrari, I. First report of the occurrence of Acartia tonsa (Copepoda, Calanoida) in the Lesina lagoon (South Adriatic Sea-Mediterranean Sea). Mar. Biod. Rec. 2008, 1, 37. [CrossRef]

60. Sei, S.; Rossetti, G.; Villa, F.; Ferrari, I. Zooplankton variability related to environmental changes in a eutrophic coastal lagoon in the Po Delta. Hydrobiologia 1996, 329, 45-55. [CrossRef]

61. Sfriso, A.; Buosi, A. Trophic status changes in the Venice lagoon during the last 40 years. In Proceedings of the 49th Congresso della Società Italiana di Biologia Marina Cesenatico (FC), Rome, Italy, 4-8 June 2018.

62. Sfriso, A. Flora and vertical distribution of macroalgae in the lagoon of Venice: A comparison with previous studies. Plat Biosyst. 1987, 121, 69-85. [CrossRef]

63. Sfriso, A.; Birkemeyer, T.; Ghetti, P.F. Benthic macrofauna changes in areas of Venice lagoon populated by seagrasses or seaweeds. Mar. Environ. Res. 2001, 52, 323-349. [CrossRef]

64. Sfriso, A.; Facca, C.; Ghetti, P.F. Temporal and spatial changes of macroalgae and phytoplankton in a Mediterranean coastal area: The Venice lagoon as a case study. Mar. Environ. Res. 2003, 56, 617-636. [CrossRef]

65. Sfriso, A.; Facca, C.; Ceoldo, S.; Silvestri, S.; Ghetti, P.F. Role of macroalgal biomass and clam fishing on spatial and temporal changes in $\mathrm{N}$ and $\mathrm{P}$ sedimentary pools in the central part of the Venice lagoon. Oceanol. Acta 2003, 26, 3-13. [CrossRef]

66. Sfriso, A.; Marcomini, A. Decline of Ulva growth in the Lagoon of Venice. Bioresour. Technol. 1996, 58, 299-307. [CrossRef]

67. Decker, M.B.; Breitburg, D.L.; Marcus, N.H. Geographical differences in behavioral responses to hypoxia: Local adaptation to an anthropogenic stressor? Ecol. Appl. 2003, 13, 1104-1109. [CrossRef]

68. Kimmel, D.G.; Boicourt, W.C.; Pierson, J.J.; Roman, M.R.; Zhang, X. A comparison of the mesozooplankton response to hypoxia in Chesapeake Bay and the northern Gulf of Mexico using the biomass size spectrum. J. Exp. Mar. Biol. Ecol. 2009, 381, 65-73. [CrossRef]

69. Mauchline, J. The biology of calanoid copepods. Adv. Mar. Biol. 1998, 33, 1-710.

70. Castro-Longoria, E. Egg Production and Hatching Success of Four Acartia Species under Different Temperature and Salinity Regimes. J. Crustac. Biol. 2003, 23, 289-299. [CrossRef]

71. El Shabrawy, G.M.; Belmonte, G. Abundance and affirmation of Paracartia latisetosa (copepoda, calanoida) in the inland lake Qarun (Egypt). Thalass. Sal. 2004, 27, 151-160.

72. Kritchagin, N. Otchet o faunisticheskikh issledovaniyakh proizvedennikh v etom godu po porutcheniyu kievskogo obsh estva estestvoispitateley na beregakh Tchernogo morya. Zap. Kiev. Obs. Estestvoispitatalei 1873, 3, 346-430. 
73. Aravena, G.; Villate, F.; Uriarte, I.; Iriarte, A.; Ibáñez, B. Response of Acartia populations to environmental variability and effects of invasive congenerics in the estuary of Bilbao, Bay of Biscay. Estuar. Coast. Shelf Sci. 2009, 83, 621-628. [CrossRef]

74. Gaudy, R.; Cervetto, G.; Pagano, M. Comparison of the metabolism of Acartia clausi and Acartia tonsa: Influence of temperature and salinity. J. Exp. Mar. Biol. Ecol. 2000, 247, 51-65. [CrossRef]

75. Cervetto, G.; Gaudy, R.; Pagano, M. Influence of salinity on the distribution of Acartia tonsa (Copepoda, Calanoida). J. Exp. Mar. Biol. Ecol. 1999, 239, 33-45. [CrossRef]

76. Biancalana, F.; Dutto, M.; Berasategui, A.; Kopprio, G.; Hoffmeyer, M. Mesozooplankton assemblages and their relationship with environmental variables: A study case in a disturbed bay (Beagle Channel, Argentina). Environ. Monit. Assess. 2014, 186, 8629-8647. [CrossRef] [PubMed]

77. Dunbar, F.N.; Webber, M.K. The phytoplankton distribution in the eutrophic Kingston Harbour, Jamaica. Bull. Mar. Sci. 2003, 73, 343-359.

78. Malej, A.; Tirelli, V.; Lučić, D.; Paliaga, P.; Vodopivec, M.; Goruppi, A.; Ancona, S.; Benzi, M.; Bettoso, N.; Camatti, E.; et al. Mnemiopsis leidyi in the northern Adriatic: Here to stay? J. Sea Res. 2017, 124, 10-16. [CrossRef]

79. Irvine, K.; Moss, B.; Bales, M.; Snook, D. The changing ecosystem of a shallow, brackish lake, Hickling Broad, Norfolk, UK II. Trophic relationships with special reference to the role of Neomysis integer. Freshw. Biol. 1993, 29, 119-139. [CrossRef]

80. Li, M.; Gargett, A.; Denman, K. What determines seasonal and interannual variability of phytoplankton and zooplankton in strongly estuarine systems? Application to the semi enclosed estuary of strait of Georgia and Juan de Fuca Strait. Estuar. Coast. Shelf Sci. 2000, 50, 467-488. [CrossRef]

81. Poggiale, J.C.; Dauvin, J.C. Long term dynamics of three benthic Ampelisca (Crustacea Amphipoda) populations from the Bay of Morlaix (western English Channel) related to their disappearance after the "Amoco Cadiz" oil spill. Mar. Ecol. Prog. Ser. 2001, 214, 201-209. [CrossRef]

82. Gucu, A.C. Can overfishing be responsible for the successful establishment of Mnemiopsis leidyi in the Black sea? Estuar. Coast. Shelf Sci. 2002, 54, 439-451. [CrossRef]

83. Hays, G.C.; Richardson, A.J.; Robinson, C. Climate change and marine plankton. Trends Ecol. Evol. 2005, 20, 337-344. [CrossRef]

(C) 2019 by the authors. Licensee MDPI, Basel, Switzerland. This article is an open access article distributed under the terms and conditions of the Creative Commons Attribution (CC BY) license (http://creativecommons.org/licenses/by/4.0/). 